Fecha de recepción: 18 de mayo de 2020 Fecha de aprobación: $1^{\circ}$ de julio de 2020 Fecha de evaluación: 29 de junio de 2020

\section{Genética, derechos humanos y política estatal en la Argentina: la creación del Banco Nacional de Datos Genéticos y del Registro Nacional de Datos Genéticos vinculados a delitos sexuales $(1987-2017)^{*}$}

\section{María Soledad Catoggio* Gabriela Irrazábal***}

Articulo adscrito al proyecto de investigación "Genética y derechos humanos: políticas y gestión de la salud y la identidad en la Argentina reciente (1980-2017). "Grupo de Investigación Programa, sociedad, cultura y religión. Periodo (2019-2021). Buenos Aires(Argentina).

** Doctora en Ciencias Sociales por la Universidad de Buenos Aires, Investigadora adjunta del Centro de Estudios e Investigaciones Laborales del Consejo Nacional de Investigaciones Científicas y Técnicas CONICET. Buenos Aires (Argentina). Correo electrónico de contacto mscatoggio@gmail.com. ORCID: https://orcid.org/0000-0002-61331626.

*** Doctora en Ciencias Sociales por la Universidad de Buenos Aires, Investigadora adjunta del Centro de Estudios e Investigaciones Laborales del Consejo Nacional de Investigaciones Científicas y TécnicasCONICET es docente de la Facultad de Ciencias Sociales de la UBA - Universidad de Buenos Aires.Desde hace 15 años integra el Centro de Estudios en Política Criminal y Derechos Humanos (CEPOC) Buenos Aires (Argentina). Correo electrónico de contacto: gabrielairrazabal@ gmail.com. ORCID https://orcid.org/0000-0003-1611-9084.

\section{Para citar este artículo}

Catoggio, M. e Irrazábal, G. (2020). Genética, derechos humanos y política estatal en la Argentina: los derroteros legislativos del Banco Nacional de Datos Genéticos y del Registro Nacional de Datos Genéticos vinculados a delitos sexuales (1987-2017). Vía luris, 29, 159-184. DOI: https:// doi.org/10.37511/viaiuris.n29a6.

DOI: https://doi.org/10.37511/viaiuris.n29a6

Licencia Creative Commons

Esta obra está bajo una Licencia Creative Commons Atribución-NoComercial-Compartirlgual 2.5 Colombia.

\section{cC)(1)(2)}




\title{
Genética, derechos humanos y política estatal en la Argentina: la creación del Banco Nacional de Datos Genéticos y del Registro Nacional de Datos Genéticos vinculados a delitos sexuales (1987-2017)
}

\author{
María Soledad Catoggio \\ Gabriela Irrazábal
}

\section{RESUMEN}

En este artículo se analiza la creación y reglamentación de dos grandes bio bancos nacionales en la Argentina: el Banco Nacional de Datos Genéticos y el Registro Nacional de Datos Genéticos Vinculados a Delitos Sexuales (1987-2017). El objetivo de este trabajo es mostrar los hilos comunes de ambos procesos, a pesar de la distancia temporal entre uno y otro. El proceso analizado a partir de los debates legislativos reconstruye los acuerdos y controversias que durante treinta años formaron parte de una discusión común: cómo articular desde el Estado la utilización de técnicas de ADN al servicio de los derechos humanos, conforme la diversificación de demandas del activismo de las víctimas y las crecientes exigencias internacionales de estandarización de estas técnicas para la investigación judicial. La solución que se impuso fue el proceso de diferenciación y división del trabajo que llevó a la creación de dos bancos separados para responder, a la vez, a distintos colectivos de víctimas, sin desentonar con las exigencias internacionales, pero cuyo efecto fue el de reforzar la figura del "ciudadano-víctima". En este decurso, el trabajo muestra el rol central del activismo de las víctimas — y sus articulaciones globales - para instalar socialmente reclamos tanto de reparación como de castigo, motorizar reformas penales punitivistas e imponer un nuevo régimen de verdad para la sociedad en general y la justicia en particular: el de la prueba genética.

Palabras clave

Genética; derechos humanos; Banco Nacional

de Datos Genéticos; Registro Nacional de Datos Genéticos; delitos sexuales; ADN. 


\title{
Genetics, human rights and state policy in Argentina: the creation of the National Bank of Genetic Data and the National Registry of Genetic Data Linked to Sexual Crimes (1987-2017)
}

\author{
María Soledad Catoggio \\ Gabriela Irrazábal
}

\begin{abstract}
This article analyzes the creation and regulation of two major national biobanks in Argentina: the National Bank of Genetic Data and the National Registry of Genetic Data Linked to Sexual Crimes (1987-2017). The aim of this paper is to show the common threads of both processes, despite the temporal distance between one and the other. The process analyzed from the legislative debates reconstructs the agreements and controversies that for thirty years were part of a common discussion: how to articulate from the State the use of DNA techniques in the service of human rights, according to the diversification of demands of victims' activism and the growing international demands for standardization of these techniques for judicial investigation. The solution that was imposed was the process of differentiation and division of labor that led to the creation of two separate banks to respond, at the same time, to different groups of victims, without clashing with international requirements, but whose effect was to reinforce the figure of the "citizen-victim". In this course, the paper shows the central role of victims' activism -and its global articulations- to socially install claims for both reparation and punishment, to drive punitivist penal reforms and to impose a new regime of truth for society in general and justice in particular: that of genetic evidence.
\end{abstract}

Keywords

Genetics; human rights; National Genetic Data Bank; National Registry of Genetic Data; sexual crimes; DNA. 


\title{
Genética, Direitos Humanos E
} Política Estatal Na Argentina: A Criação Do Banco Nacional De Dados Genéticos E O Registo Nacional De Dados Genéticos Ligados A Delitos Sexuais (1987-2017)

\author{
María Soledad Catoggio \\ Gabriela Irrazábal
}

\section{RESUMO}

Este artigo analisa a criação e regulamentação de dois grandes biobancos nacionais na Argentina: o Banco Nacional de Dados Genéticos e o Registo Nacional de Dados Genéticos ligados a crimes sexuais (1987-2017). O objectivo deste trabalho é mostrar os fios comuns de ambos os processos, apesar da distância temporal entre um e o outro. O processo analisado a partir dos debates legislativos reconstrói os acordos e controvérsias que durante trinta anos fizeram parte de uma discussão comum: como articular a partir do Estado o uso de técnicas de ADN ao serviço dos direitos humanos, de acordo com a diversificação das exigências do activismo das vítimas e as crescentes exigências internacionais de normalização destas técnicas para a investigação judicial. A solução que foi imposta foi o processo de diferenciação e divisão do trabalho que levou à criação de dois bancos separados para responder a diferentes grupos de vítimas, sem estar desfasado das exigências internacionais, mas cujo efeito foi reforçar a figura do "cidadão-vítima". Neste processo, o trabalho mostra o papel central do activismo das vítimas-e das suas articulações globais-na instalação social de exigências de reparação e punição, impulsionando reformas penais punitivistas e impondo um novo regime de verdade para a sociedade em geral e de justiça em particular: o das provas genéticas.

Palavras-chave

Genética; Direitos Humanos; Banco Nacional

de Dados Genéticos; Registo Nacional de Dados

Genéticos; Ofensas Sexuais; ADN. 


\title{
Génétique, Droits De L'homme Et Politique De L'état En Argentine : La Création De La Banque Nationale De Données Génétiques Et Du Registre National Des Données Génétiques Liées Aux Délits Sexuels (1987-2017)
}

\author{
María Soledad Catoggio \\ Gabriela Irrazábal
}

\begin{abstract}
RÉSUMÉ
Cet article analyse la création et la réglementation de deux grandes biobanques nationales en Argentine : la Banque nationale de données génétiques et le Registre national de données génétiques liées aux crimes sexuels (1987-2017). L'objectif de cet article est de montrer les points communs des deux processus, malgré la distance temporelle entre l'un et l'autre. Le processus analysé à partir des débats législatifs reconstruit les accords et les controverses qui, pendant trente ans, ont fait partie d'une discussion commune : comment articuler depuis I'État l'utilisation des techniques d'ADN au service des droits de l'homme, conformément à la diversification des demandes de l'activisme des victimes et aux demandes internationales croissantes de standardisation de ces techniques pour les enquêtes judiciaires. La solution qui a été imposée a été le processus de différenciation et de division du travail qui a conduit à la création de deux banques distinctes pour répondre aux différents groupes de victimes, sans être en décalage avec les exigences internationales, mais dont l'effet a été de renforcer la figure du "citoyen-victime". Dans ce processus, l'ouvrage montre le rôle central du militantisme des victimes-et de ses articulations mondiales-dans l'installation sociale des demandes de réparation et de punition, dans la conduite de réformes pénales punitivistes et dans l'imposition d'un nouveau régime de vérité pour la société en général et la justice en particulier: celui de la preuve génétique.
\end{abstract}

Mots-clés

Génétique; Droits de l'homme; Banque nationale de données génétiques; Registre national des données génétiques; Infractions sexuelles; ADN. 


\section{INTRODUCCIÓN}

A mediados del siglo $X X$, el descubrimiento de la secuencia de ADN (ácido desoxirribonucleico) del genoma humano tuvo repercusiones que no solo revolucionaron el campo de la ciencia y de la salud, sino que impactaron en distintos órdenes de la vida de las personas, afectando sus derechos.

Según Cohen Salama (1992) y Penchaszadeh (2012), desde los años ochenta en adelante América Latina fue pionera en la realización de estudios genéticos para esclarecer delitos de lesa humanidad como las desapariciones forzadas y la restitución de identidad de niñas y niños apropiados en contextos dictatoriales. El desarrollo de la genética forense se articuló a partir de redes de experticia y activismo humanitario trasnacional y tuvo un decisivo impacto en la relación entre democracia, justicia, recomposición de familias e identidades en la Argentina, tal como sostienen Gibbons y Novas (2007); Smith (2017) y Catoggio (2019a).

Sin embargo, como señalan López Beltrán, Wade, Restrepo y Ventura Santos (2017) esta misma potencialidad de los nuevos usos de la genética vino a significar en otros ámbitos una amenaza para el ejercicio pleno de derechos, afectando el derecho a la intimidad, aportando argumentos de discriminación fundada en características genéticas, allanando el camino para el resurgimiento de aventuras eugenésicas, racistas y fundamentaciones lombrosianas del perfil delictivo.

El descubrimiento de la llamada "huella genética", llevado adelante por el científico británico Alec Jeffreys en 1984, formó parte de esta "revolución genómica". Este hallazgo, que permitió la identificación de los individuos, antes solo posible mediante el sistema dactiloscópico, comenzó a ser utilizado por áreas de investigación judicial para identificar a autores de delitos a partir de la evidencia recolectada en las escenas del crimen. Según Guerrero Moreno (2011) y Machado y Granja (2020), desde los años noventa los perfiles de ADN se constituyeron en una herramienta de uso común en las investigaciones forenses de los países del norte global, y las legislaciones comenzaron a adecuarse para generar y ampliar el alcance de los bancos de almacenamiento de datos genéticos. Como documentan Maguire, McCallum, Storey y Whitaker (2014), la normativa fue habilitando, primero, las bases de datos genéticos de condenados por delitos sexuales, luego por homicidios $y$, en algunos casos, hasta detenidos por fuerzas de seguridad — sin proceso ni condena-. Para el año 2000, especialmente en el marco europeo, según Goodwin (2017), se plantearon una serie de regulaciones para la constitución y elaboración de biobancos y estándares de trabajo en el área de genética forense, propiciando el respeto por los derechos de las personas.

Estos hallazgos y avances en materia de usos de técnicas de ADN, que fueron casi contemporáneos en el plano global, tuvieron un desarrollo desacompasado en la Argentina. La creación en 1987, mediante la Ley 23.511, del Banco Nacional de Datos Genéticos (BNDG) para restituir la identidad de los niños y niñas apropiados ilegalmente durante la última dictadura tuvo el ya señalado carácter pionero en el mundo. En cambio, aunque las iniciativas para la creación de un biobanco para el esclarecimiento de delitos sexuales comenzaron a finales de los noventa, recién logró concretarse en 2013 con la creación del Registro Nacional de Datos Genéticos Vinculados a Delitos contra la Integridad Sexual (RNDG), mediante la Ley 26.879. Paradójicamente, uno de los argumentos centrales para tal concreción fue no quedar a la saga de los estándares internacionales en la materia.

Ambos biobancos surgieron como una respuesta estatal, dada en distintas coyunturas, a las demandas de diversos colectivos de víctimas, con distintos impactos o ecos de la agenda internacional sobre la materia. En este escenario, nos preguntamos: ¿En qué contextos surgieron esas demandas de las víctimas? ¿Cómo se articularon o entraron en tensión con el debate legislativo? ¿Qué rol tuvo el Estado y la agenda internacional en el impulso o postergación de las iniciativas parlamentarias relativas a dichos biobancos? El objetivo de este artículo es poner en evidencia cómo, aún con este desfasaje temporal, los debates de creación de uno y otro biobanco, así como las medidas relativas a la regulación de los usos de las técnicas de ADN, formaron parte de una disputa común desde los años ochenta hasta la actualidad. En ese marco, en este artículo pondremos el foco en los debates, alianzas y conflictos emergentes en torno a la constitución del Banco Nacional de Datos Genéticos (BNDG) y del Registro Nacional de Datos Genéticos Vinculados a Delitos contra la Integridad Sexual (RNDG), en el ámbito del poder legislativo de la Argentina. 
* Genética, derechos humanos y política estatal en la Argentina: la creación del Banco Nacional de Datos Genéticos y del Registro Nacional de Datos Genéticos vinculados a delitos sexuales

\section{GENÉTICA, DERECHOS HUMANOS Y POLÍTICA ESTATAL: UN ESTADO DE LA CUESTIÓN}

La relación entre genética, derechos humanos y política estatal ha sido ampliamente abordada en la literatura académica. Estos antecedentes pueden ordenarse en cinco grandes líneas: a) genética, derechos humanos y salud pública; b) genética, derechos humanos e identidad; c) genética, derechos humanos y sistema de justicia penal/política criminal; d) genética, derechos humanos y políticas estatales de almacenamiento o conservación de datos genéticos; y e) genética, evidencia e imaginarios sociales.

El primer grupo reúne trabajos como los de Bergel (2002), Penchaszadeh (2012), Santaló y Casado (2016) y Gómez Ojero y Martínez (2016), que desde enfoques bioéticos señalan diversos dilemas éticos, jurídicos y sociales de la relación entre derechos humanos, genética y salud.

El segundo sintetiza producciones, como las de Pestoni y Carracedo Álvarez (1998), Wagner (2008), Bernardi y Fonderbrider (2007), Casado y López Ortega (2015), Smith (2017) y Parra, Zapico y Ubelaker (2020), ligadas al desarrollo de la genética forense en la identificación de restos humanos y procesos de restitución de identidad en distintos contextos. Aquí situamos también abordajes como los de Bernath (2007) y Gesteira (2014), que analizan estos procesos tanto desde el ángulo biográfico, como estatal.

El tercer grupo reúne estudios como los realizados por Vargas Ávila (2010), Carracedo, Salas y Lareau (2010), Caruso Fontán (2012), Smith (2017) e Irrazábal, Dallorso, Cesaroni y Costa (2018), que problematizan la utilización de identificadores de ADN en criminalística o en el sistema de justicia penal.

Por último, existe una abundante literatura acerca de la protección de datos genéticos, almacenamiento, conservación y derechos fundamentales. Los trabajos de Paz Karaman (2015) y Sánchez, Carracedo y Abraham (2017) son buenos ejemplos.

En otro plano, Rose ([2007] 2012) ofrece una marco más general para problematizar la relación entre genética, derechos humanos y política de los Estados, encuadrándola en la perspectiva global de las "políticas de la vida", emergentes entre fines del siglo XX y comienzos del siglo XXI. En esa línea, que incorpora a su objeto de análisis las visiones de futuro, los temores y las especulaciones sobre estos fenómenos como propios de la "vida emergente", López Beltrán et ál. (2017) y Catoggio (2019a) han hecho nuevos aportes a partir de la indagación de la relación entre genética y creencias e imaginarios sociales.

Existe, sin embargo, un vacío de producciones que a partir de un objeto empírico específico hagan dialogar estos distintos desarrollos existentes en materia de genética, derechos humanos y política estatal, sin caer en la bifurcación habitual entre los estudios optimistas acerca de la "genética de los derechos humanos" y los enfoques pesimistas, críticos de la "vigilancia genética de la población y sus usos punitivistas", que dividen el campo, tal como señala Catoggio (2019a). En este sentido, el análisis propuesto de la creación de dos biobancos, como el BNDG y el RNDG, situados en coyunturas muy distintas y con funciones a priori opuestas, permite establecer un diálogo y una discusión entre los distintos enfoques existentes que puede rastrearse en los debates legislativos sostenidos durante treinta años. Estos debates son un prisma privilegiado para abordar acuerdos y controversias que excedían el recinto parlamentario e involucraban a un amplio abanico de actores: familiares de víctimas del terrorismo de Estado, familiares de víctimas de delitos comunes, partidos políticos, actores judiciales, formadores de opinión pública e interlocutores globales. Sistematizamos el debate público en cuatro momentos de consensos y disensos en torno a la especificidad de cada uno de los bancos de datos genéticos: 1987-2004; 2004-2006; 2006-2009 y 2009-2017.

\section{METODOLOGÍA}

Este artículo es parte de un proyecto más amplio titulado "Genética y derechos humanos: políticas y gestión de la salud y la identidad en la Argentina", financiado por el Consejo Nacional de Investigaciones Científicas y Técnicas de Argentina (Conicet). Para este artículo, trabajamos con la técnica de análisis documental, que según Valles (1997) es el estudio de la documentación producida por los actores sociales involucrados (registros escritos y simbólicos). En nuestro caso incluye, además, el análisis de documentos institucionales, boletines, folletería, imágenes y artículos de prensa. Los criterios de selección de textos que conforman nuestro corpus documental incluyen en primer lugar el tipo de género, origen y finalidad, tal como indica 
Pérez Hernández (2002). En este punto contemplamos textos cuya finalidad estaba orientada a la modificación de normativa o a un posicionamiento público sobre las normativas en discusión. Se trata, por una lado, de textos legislativos, originarios de cámaras de senadores o diputados y, por el otro, de resoluciones administrativas, sentencias judiciales y artículos de prensa vinculados a los debates legislativos analizados. Además de considerar el tipo de texto, para integrar el corpus se contemplaron los criterios teórico-conceptuales con relación a acuerdos y controversias en la constitución de los bancos genéticos analizados, vínculos entre las técnicas de ADN y los derechos humanos, el activismo de las víctimas, las respuestas del Estado y las exigencias internacionales en materia de investigación judicial. En concreto, nuestro corpus está compuesto por 45 documentos: 24 de ellos corresponden al tratamiento y debate legislativo de las leyes 23.511, 26.548, 26.879 (incluyen debates de las sesiones de Cámara de Diputados y Senadores, reuniones de comisiones legislativas con asesores expertos, trámite parlamentario, proyectos de ley y texto final de la ley aprobada). A su vez, consideramos las leyes nacionales modificatorias de la ejecución de la pena, una (1) resolución del Ministerio de Justicia de la Argentina y tres (3) sentencias judiciales relacionadas. Por último, incorporamos artículos de prensa vinculados con los debates legislativos analizados. Los criterios analíticos incluyeron, siguiendo a Hernández (1996), la lectura y reconocimiento, la síntesis-transformación y la representación y recuperación de los materiales, codificando y construyendo categorías que se presentan en la sección de resultados.

La periodización propuesta para el análisis responde a la condensación de acontecimientos que enhebran la historia parlamentaria de los dos biobancos bajo estudio. Evitando una lectura teleológica, encontramos en estas coyunturas la convergencia de: hechos que causan conmoción social con amplia repercusión mediática, picos de efervescencia del activismo de las víctimas y sus familiares, diversas iniciativas de proyectos de ley, la sanción efectiva de leyes, sus modificaciones y la concreción de reformas penales que tejen hilos comunes entre ambos derroteros parlamentarios. En este sentido, durante el primer periodo, 1987-2004, se destacan la creación del BNDG, con amplio consenso legislativo, y las disputas por la definición de su incumbencia. El segundo, 2004-2006, sacudido por crímenes que causan conmoción social, se caracteriza por el auge de demandas punitivistas que dan lugar a la creación del Registro de Huellas Genéticas en el marco de la Policía Federal, al convenio de cooperación entre dichas fuerzas de seguridad y el BNDG y a un proceso de ampliación de funciones de incumbencia del BNDG. El tercero, 2006-2009, está marcado por álgidos disensos parlamentarios, por la resolución de circunscripción de funciones a las causas de lesa humanidad vinculadas a la última dictadura y por el traslado del BNDG a la órbita del Ministerio de Ciencia. Durante este periodo, se sanciona la extracción de ADN compulsivo para todo requerimiento judicial y se abre el horizonte de creación del RNDG. Por último, entre 2009-2017 tiene lugar tanto la creación del RNDG, como su reglamentación. Se impone el "derecho a la verdad de las víctimas" como mandato común de la política pública en materia de biobancos, en el marco de una tendencia creciente de adecuación estatal a estándares internacionales.

\section{RESULTADOS Y DISCUSIÓN}

\section{La universalidad del derecho a la identidad: la constitución del Banco Nacional de Datos Genéticos (BNDG) y su proyección global (1987-2004)}

Desde el propio campo de los derechos humanos en la década de los ochenta, en Argentina un grupo de mujeres nucleadas en Madres de Plaza de Mayo y en Abuelas de Plaza de Mayo, junto a otros familiares de desaparecidos, recurrieron a expertos del campo de la genética con preguntas concretas. ¿La sangre de las abuelas serviría para la identificación de sus nietos, secuestrados durante la dictadura militar (1976-1983)?, ¿era posible determinar si un cuerpo había estado o no en un ataúd a partir del análisis de ADN?, ¿era cierto que los huesos de los bebés se desintegraban?, ¿se podía determinar si una mujer había estado o no embarazada a partir del análisis de sus huesos? Expertos como Di Lonardo, Orrego, Darlu, King y Baur (1984), Joyce y Stover (1991) y King (1992) narran cómo aquellas preguntas de los familiares fueron orientando novedosas áreas disciplinares de investigación a nivel internacional y moldeando trayectorias científicas locales.

Esta convergencia entre expertos internacionales, familiares de desaparecidos, actores judiciales y políticos hizo posible la creación del Banco Nacional de Datos Genéticos en la Argentina en 1987, mediante la Ley 23.511. Se trataba de la primera 
experiencia a nivel mundial de un biobanco estatal que ponía de manifiesto la relación entre genética, salud, identidad y derechos humanos. Según Joyce y Stover (1991) fue también de esta convergencia que surgió el Equipo Argentino de Antropología Forense, que devino en un modelo de trabajo para la región y el globo. La Argentina fue pionera en la construcción del vínculo estatal entre genética y derechos humanos que, luego, propició desarrollos internacionales de genética humanitaria, forense $y$, desde mediados de los noventa, de laboratorios de criminalística.

La Ley 23.511, que estableció la constitución del BNDG en Argentina, se materializó a partir de un proyecto presentado por el poder ejecutivo nacional, que en el ámbito del Congreso de la Nación se sancionó con total consenso. No hubo debates o contraposiciones públicas por parte de los legisladores el día de la sesión de tratamiento del proyecto, ocurrida el 31 de octubre de 1986, ni documentos adjuntos de disidencia. La norma sancionada establecía al BNDG en el marco de un laboratorio de un hospital público de la Ciudad de Buenos Aires, entonces Capital Federal y dependiente administrativamente de la Nación.

El texto de la norma puesto a consideración de los legisladores aclaraba en su articulado que se refería a casos de filiación de niños y niñas desaparecidos o nacidos en cautiverio durante la dictadura de 197683. A su vez, el Poder Ejecutivo Nacional no solo ratificaba el objetivo de la constitución del BNDG, sino que manifestaba su confianza en la ciencia y la tecnología para la búsqueda de la verdad: "Ios avances de la ciencia permiten contar con análisis hemogenéticos y de histocompatibilidad capaces de producir pruebas de nexo biológico de asombrosa precisión, así como de descartar, sin margen de error, una paternidad falsamente atribuida" (Honorable Cámara de Senadores de la Nación - HCSN, 1986, 32aㅡ reunión, 23aㅡ sesión ordinaria, p. 4394).

Esta ley fue aprobada el 13 de mayo de 1987 y publicada en el boletín oficial en el mes de julio de ese mismo año. Si bien en el plano legislativo la constitución del BNDG y la creencia en la ciencia como pilar fundamental para la búsqueda de la verdad se dio de manera consensuada, en el ámbito de organizaciones de familiares de desaparecidos como Madres de Plaza de Mayo hubo cuestionamientos y discusiones. De acuerdo con Catoggio (2019b), por un lado, un sector identificado con los reclamos de "aparición con vida" manifestaba resistencia a aquellos discursos que daban por muertos a los desaparecidos y cuestionaba la evidencia forense en tanto "prueba científica" que pudiese dar por muertos a los familiares desaparecidos. Así, la creencia en la "asombrosa precisión de la ciencia" manifestada por los legisladores generaba desconfianza en algunas de las víctimas y familiares del terrorismo de Estado. Por el otro, al establecer la creación del BNDG “a fin de obtener y almacenar información genética que facilite la determinación y esclarecimiento de conflictos relativos a la filiación" (cfr. ley 23.511, artículo 1), dejaba abierta la posibilidad de que el banco trabajase no solo con casos de lesa humanidad, sino con otros de filiación en general (sustitución de identidad, adopciones ilegales o paternidad presunta en derecho de familia). De este modo, la creación consensuada en el plano legislativo dejaba abiertos disensos, tanto en el seno de las organizaciones de derechos humanos como entre los expertos vinculados al banco, acerca de los alcances o límites de su incumbencia.

Como veremos, en los años siguientes (2006, 2007, 2009) volvió a tratarse la ley del BNDG en el Congreso de la Nación para establecerlo como un banco exclusivo de víctimas de la dictadura (1976-1983). En esas ocasiones, un grupo de legisladores de la Unión Cívica Radical (UCR), que había sido el partido gobernante durante la sanción de la Ley 23.511, junto con un partido entonces joven, Afirmación para una República Igualitaria (ARI), fundamentaron su rechazo a la circunscripción de sus funciones. Manifestaban que, aunque el espíritu original del BNDG había sido esclarecer casos de filiación vinculados a la sustracción de niños en la dictadura; atendiendo al pedido de una abuela de Plaza de Mayo, con el acuerdo unánime de senadores y diputados se había resuelto en aquel entonces que el BNDG interviniera en casos de filiación en general (Honorable Cámara de Diputados de la Nación - HCDN, 2009, 15 reunión, $9^{\circ}$ sesión ordinaria).

De este modo, los legisladores fundaban en el activismo de las víctimas el espíritu de la ley: la universalidad del derecho a la identidad tenía su fundamento en el deseo mismo de los familiares y víctimas del terrorismo de Estado. Al afirmar que la discusión acerca del ámbito de aplicación del BNDG ya había sido saldada a finales de los ochenta, se subrayaba que había sido por pedido de una abuela - y en representación de un grupo de integrantes de organismos de DDHH_que se había ampliado 
la función del BNDG para que pudiese utilizarlo toda la sociedad.

Las fuentes del debate hacen alusión a que fue un pedido expreso de María Isabel Chorobik de Mariani, entonces — y hasta 1989— presidenta de Abuelas de Plaza de Mayo: "por aquel entonces, la presidenta de Abuelas, nuestra querida Chicha Mariani, expuso ante quien quisiera oír sus motivos. Habló de solidaridad, del futuro, de la obligación del Estado de garantizar los derechos y atender las necesidades de todas las personas" (Diputada Gil Lozano, HCDN, 2009, periodo 127, reunión 15, p. 192).

La tensión en torno al ámbito de aplicación del BNDG, que quedó resuelta en Ley 23.511, en su artículo 1, no bastó para saldar el conflicto abierto entre los actores sociales involucrados. En la práctica, el BNDG con sede en el Hospital Durand de la Ciudad de Buenos Aires intervenía en casos de lesa humanidad, de filiación en general, hacía estudios propios del área de salud (compatibilidad en trasplantes, enfermedades de origen genético) y también, por requerimiento judicial, tenía incumbencia en casos penales.

Como desarrollaremos en el apartado siguiente, el auge de políticas punitivistas a mediados de la década del 2000 derivó en un in crescendo de la presión por la ampliación del área de incumbencia del BNDG. En este nuevo clima social y político, se reabrió el conflicto en el plano legislativo, dando lugar a tanto la circunscripción de la función del BNDG como a su traslado y a la concreción de modificaciones generales en cuestiones de política criminal.

\section{Reclamos sociales de castigo, inseguridad y violencia: un banco de datos genéticos también para violadores y delincuentes comunes (2004-2006)}

El gobierno de Néstor Kirchner, iniciado 2003, inauguró en Argentina una nueva etapa de políticas de memoria, verdad y justicia ${ }^{1} 3$ Siguiendo a Kessler y

1 Las principales medidas fueron la nulidad de las leyes de Obediencia Debida y Punto Final por el Congreso de la Nación, que permitió la reanudación de los juicios por delitos de lesa humanidad; la recuperación y resignificación de la Escuela Mecánica de la Armada, uno de los principales centros
Gayol (2018), como parte de una política estatal de derechos humanos, el gobierno de Kirchner tomó distancia del tratamiento represivo de la protesta social y piquetera que había caracterizado a los gobiernos previos y se apropió simbólicamente de las muertes de Maximiliano Kosteki y Darío Santillán. Sin embargo, este reconocimiento a las víctimas de las fuerzas de seguridad del Estado convivió, a partir de 2004, con toda una serie de reformas penales en materia de política criminal, que fueron muy cuestionadas por diversos sectores del campo de los derechos humanos. Se elevaron las penas de los delitos de secuestro extorsivo, de portación de armas, de homicidios y de violaciones seguidas de muerte. En coincidencia con Lorenc Valcarce (2003), estas transformaciones respondían a demandas y discursos que desde los tempranos años noventa habían logrado instalar la cuestión del delito, ligada a "la inseguridad", como problema público en el ámbito nacional y como parte intrínseca del debate político y de la opinión pública. Tal como precisan Cesaroni, Feldman e Irrazábal (2014) y Sodini y Garbi (2014), fue a partir de las campañas políticas para las elecciones de 1999 (nacionales y provinciales) que la cuestión de la inseguridad se tornó un eje central del discurso político y se consolidaron los discursos denominados como de "mano dura".

Las reformas penales del año 2004 pueden considerarse como paradigmáticas respuestas a estos reclamos; a pesar de que, al tener como su principal ideólogo al abogado Roberto Durrieu, un exfuncionario de la dictadura militar, reavivaban el pasado que el gobierno buscaba dejar atrás. Fue entonces, tras la conmoción social causada por una serie de crímenes, que cobró fuerza el reclamo por la inseguridad, que interpelaba socialmente a "sentirla como propia". A fines de 2003 una joven, Lucila Yaconis, fue hallada muerta luego de una violación en las inmediaciones de un paso a nivel del ferrocarril en el barrio de Núñez de la Ciudad de Buenos Aires. A fines de marzo de 2004, un joven de 23 años, Axel Blumberg, fue secuestrado por delincuentes comunes y apareció muerto en un barrio del conurbano de la provincia de Buenos Aires. La movilización social

clandestinos de represión, que fue declarada Espacio para la Memoria y para la Promoción y Defensa de los Derechos Humanos el 24 de marzo de 2004; el histórico pedido de "perdón" en nombre del Estado y retiro de los cuadros de los excomandantes Jorge Rafael Videla y Reynaldo Benito Bignone del Colegio Militar; la declaración del 24 de marzo como efeméride nacional, la nulidad de los indultos a los represores en julio de 2007, entre otras. 
provocada por esos crímenes que causan conmoción dio lugar a la proliferación de asociaciones de familiares, padres y madres de víctimas movilizados para su esclarecimiento. En ambos casos, los padres de las víctimas, Isabel Yaconis y Juan Carlos Blumberg, respectivamente, se convirtieron en figuras icónicas como emprendedores de demandas al Estado. Así, a las asociaciones de familiares de víctimas de la represión de las fuerzas de seguridad ya existentes desde comienzos de los años noventa se sumaron otras con nuevas demandas ${ }^{2}$. Blumberg se manifestó en el espacio público, movilizando a los vecinos tras el reclamo de reformas legislativas penales, y cobró gran visibilidad. A su vez, en 2004, se creó la Asociación Madres del Dolor, encabezada por Isabel Yaconis. Esta asociación se convirtió en un actor clave en el activismo para el endurecimiento de penas a condenados por delitos sexuales y el reclamo de registros de ADN que facilitaran la identificación de los responsables de esos crímenes ${ }^{3}$. De este modo, el reclamo de endurecimiento de las penas trajo otro asociado: el del ámbito de intervención y jurisdicción del BNDG.

La presencia de padres, madres y familiares de víctimas tanto de delitos comunes como de lesa humanidad y de violencia institucional se volvió frecuente en los debates legislativos, ya fuera para avalar o impugnar las discusiones en curso. Fue así que esa coyuntura estuvo atravesada por diversos procesos convergentes: se aumentaban las penas para delitos considerados graves, se avanzaba en los juicios de lesa humanidad y se solicitaban registros de ADN para "violadores" o "para cualquier condenado", disputando el ámbito de intervención y la jurisdicción del BNDG.

En ese marco, una comisión legislativa discutió en 2004 la creación de un registro de ADN para agresores sexuales, la extracción compulsiva de ADN y el

2 Una asociación pionera fue la Coordinadora contra la Represión Policial e Institucional que reunía a familiares de víctimas de "gatillo fácil". A su vez, durante los años 2001-2002, en el marco de una crisis económica y elevados niveles de pobreza, se desarrollaron movimientos sociales y protestas masivas que tuvieron respuesta represiva por parte del Estado a través de sus fuerzas de seguridad federales o provinciales. La madres, padres, hermanos y amigos de las víctimas de la represión estatal a la protesta social también se nuclearon en organizaciones de familiares.

3 Para un estudio de los procesos de victimización articulados a partir de demandas de criminalización y sus efectos de desplazamiento: de la responsabilidad social a la individual, puede verse Pitch (2003). resguardo de las muestras en el BNDG del Hospital Durand. Durante la reunión, algunos legisladores indicaron que se encontraban allí reunidos con urgencia por presión de la "agenda mediática", ocupada de los crímenes que mencionamos antes ([Diana] Conti, en Comisión de Justicia y Asuntos Penales del Senado de la Nación Argentina-CJyAPSN-, 2004). En aquel encuentro legislativo para debatir el Ilamado "registro de ADN de violadores" en el marco de la discusión de las reformas penales más generales, se recuperó un proyecto de ley presentado por Miguel Ángel Pichetto. Se trataba de un político de alto perfil, presidente del bloque justicialista en el Senado desde 2002, cargo que ejerció hasta 2019, cuando decidió integrase como vicepresidente a la fórmula presidencial de Mauricio Macri, por Juntos por el Cambio. En el año 1998, Pichetto había presentado ya un proyecto de ley para la creación de un banco de datos de ADN de condenados por delitos sexuales que, además, contemplaba la incorporación de una foto en el registro y la publicidad de los rostros de los condenados cerca de los domicilios donde fueran a radicarse una vez cumplida su pena en los establecimientos penales. Este proyecto causaba rechazo entre los legisladores, no por el registro de ADN, sino por la moción de publicidad de la fotografía de los condenados por delitos sexuales. Por ese motivo, perdió estado parlamentario y fue presentado en la Cámara de Diputados en reiteradas oportunidades hasta que, finalmente, después de ser tratado por la comisión legislativa antes referida de 2004, caducó. Las iniciativas parlamentarias de Pichetto — que se reiteraron entre 2005 y 2013 fueron parte de una serie más amplia de proyectos legislativos presentados sobre la materia ${ }^{4}$.

En el recinto parlamentario, el estancamiento del debate en cuanto al registro de ADN de condenados por delitos sexuales se manifestaba también en expresiones que indicaban que no era necesario una ley nacional, ya que el registro se podía hacer por resolución administrativa del Ministerio de Justicia (Jorge Agúndez en CJyAPSN, 2004, p. 4). Sin embargo, antes que preocuparles el problema constitucional que aparejaba el ADN, al introducir al cuerpo de los ofensores sexuales como evidencia que "declaraba contra sí mismo", los legisladores

4 Nos referimos a las iniciativas de la diputada Nora Chiaccio, del Peronismo Federal, presentadas en 2001, 2003 y 2005 en la Cámara de Diputados. Véase, La Nación, "Para identificar a violadores. Genetistas instan a crear un banco de ADN de criminales", 17 de enero de 2006. 
consideraban que había limitaciones presupuestarias y técnicas para el resguardo de las muestras:

Sé que el tema del ADN puede ser cuestionado. Personalmente, creo que sería razonable hacer ese registro de ADN [...] No tengo la percepción de que haya un problema constitucional sobre la declaración contra sí mismo, porque no hubo hecho delictivo todavía [...] Digo, teníamos que haber tenido el tema operativo, costos, etcétera. Es complicadísimo [...] Independientemente de eso, uno guarda la muestra cuando la persona ya fue condenada pero tiene, todavía, su libre albedrío de elegir, después, cometer otro delito o no. (Vilma Ibarra en CJyAPSN, 2004, p. 4)

Tanto la Policía Federal como la Gendarmería Nacional tenían sus laboratorios forenses y realizaban análisis utilizando técnicas diferentes, acarreando problemas relativos a la "conservación de las muestras":

¿Quiénes guardan en la actualidad muestras de ADN? Gendarmería, Policía Federal y el Banco Nacional de Datos Genéticos [...] el drama que tenemos, en estos momentos, en los temas en los que está complicado el ADN, es el de la conservación. Generalmente, no se puede conservar bien. Policía lo está haciendo bastante bien y Gendarmería, también; con dos métodos absolutamente distintos. (Cecilio Pagano, Juez invitado como experto en CJyAPSN 2004, p. 4)

Aún con estos obstáculos, el Ministro de Justicia, Gustavo Béliz creó ese año el Registro de Huellas Genéticas por medio de una resolución administrativa. Según la Resolución 415/2004, el objetivo era almacenar huellas genéticas asociadas a evidencia obtenida en las escenas del crimen o a las prendas de las víctimas o que proviniese de perfiles genéticos realizados en el curso de procesos judiciales. Además, se proponía utilizar "la tecnología de vanguardia, como lo es la determinación de ADN para la construcción de la huella genética [...] para culpar o exculpar a personas sindicadas como responsables" (Res. 415/2004, Considerando, párr. 2). Si bien el registro quedaba bajo la jurisdicción del Registro Nacional de Reincidencia del Ministerio de Justicia, se indicaba que los análisis de ADN — no codificante - sobre las muestras biológicas extraídas para determinar la huella genética se realizarían en el laboratorio químico de la Policía Federal Argentina (art. 8) o en los organismos públicos autorizados por convenio (art. 11 inc. c), como el BNDG 5 .

Esta resolución, si bien se presentó a la opinión pública como una respuesta a los crímenes que causan conmoción social, tuvo su origen, por un lado, en los proyectos de ley elaborados por legisladores oficialistas desde 1998 y, por el otro, en un documento presentado en sucesivas oportunidades al Ministro de Justicia por integrantes de la Sociedad Latinoamericana de Genética Forense desde 2003 en adelante, tal como señala Penacino (2008). Los integrantes argentinos de esta sociedad científica contaban con amplia trayectoria en los análisis forenses de ADN en distintos laboratorios (Policía Federal, Colegio de Farmacéuticos y Bioquímicos; Servicio de Huellas Genéticas de la Facultad de Farmacia y Bioquímica de la Universidad de Buenos Aires) ${ }^{6}$ y habían intervenido en casos criminales y desastres masivos, como el atentado a la Embajada de Israel en la ciudad de Buenos Aires en 1992 y la Asociación Mutual Israelí Argentina en 1994, como documentan Corach, Penacino y Sotelo (1994) y Corach, Sala, Penacino y Sotelo (1995). Según la propuesta de estos genetistas, el registro de huellas genéticas de condenados por delitos sexuales establecería dos bases de datos: una con muestras biológicas de condenados por delitos graves y otra con información genética de evidencias de casos no resueltos. Siguiendo a Penacino (2008), el objetivo que perseguían era que, ante la comisión de un delito, los magistrados pudiesen ordenar la comparación entre la evidencia recolectada de la escena del crimen y de las bases de datos de los condenados.

Dadas las dificultades operativas para implementar el registro, el Ministerio de Justicia rubricó un convenio con el BNDG para que interviniese también en estos casos. Así, el BNDG ampliaría su ámbito de intervención ocupándose de hijos de desaparecidos

5 Véase La Nación, "Banco de Datos Genéticos", $1^{\circ}$ de junio de 2004.

6 El servicio de huellas genéticas de la Facultad de Farmacia y Bioquímica de la Universidad de Buenos Aires fue el primer centro institucional de biología molecular forense fundado en 1991 dirigido por Daniel Corach. El laboratorio de análisis de ADN del Colegio Oficial de Farmacéuticos y Bioquímicos de la Capital Federal funciona desde el año 2003, bajo la dirección del Dr. Gustavo Penacino (ver Colegio Oficial de Farmacéuticos y Bioquímicos de Capital Federal, s. f.). 
(1976-83), compatibilidad para transplantes, enfermedades de origen genético y delitos sexuales

Aunque, en la práctica, el registro de huellas genéticas de delitos sexuales no llegó a implementarse (La Nación, 2006; Penacino, 2008), la sanción de la Resolución 415/2004 y la ampliación del ámbito de intervención del BNDG generó un extenso y álgido debate que solo se resolvería más tarde con dos propuestas legislativas que separaban a los bancos.

\section{La división del trabajo científico y un mandato común: dos bancos nacionales y la extracción compulsiva de datos genéticos (2006-2009)}

Con el transcurso de los años y en paralelo al avance de las técnicas de ADN y la presión de distintos actores sociales, el ámbito de aplicación del BNDG se fue ampliando hasta incluir, como vimos, por resolución del Ministerio de Justicia de la Nación (Res. 415/2004), un registro de ADN de condenados por delitos sexuales y otros delitos. Esta situación derivó en el año 2006 en la presentación de un nuevo proyecto de ley, esta vez de creación de un Instituto Nacional de Datos Genéticos (INDG) en el ámbito del Ministerio de Justicia y Derechos Humanos para resguardar las muestras de víctimas de la dictadura de 1976 (cfr. Expte. 5899-D-2006). Según el autor del proyecto, Remo Carlotto, el traslado del material biológico y la creación de este instituto particular eran necesarios para acelerar las causas de las víctimas, pues los procesos se demoraban porque el banco del Hospital Durand no tenía dedicación exclusiva y sus técnicas de análisis debían modernizarse (Página 12, 2006) ${ }^{8}$. En los fundamentos de su proyecto, que fue acompañado por un grupo de legisladores del partido gobernante, el Frente para la Victoria, del socialismo, del Partido Convergencia y por el Secretario de Derechos Humanos de la Nación, manifestaba que la demora en la resolución de casos podría subsanarse con un "banco exclusivo" dedicado al esclarecimiento de delitos de lesa humanidad:

7 Véase La Nación, "Para identificar a violadores. Genetistas instan a crear un banco de ADN de criminales", 17 de Enero de 2006.

8 Véase página 12, "El banco de datos genéticos ahora se quedó sin quórum", 15 de diciembre de 2006.
El paso del tiempo para los jóvenes secuestrados y los familiares que los buscan aun siendo ancianos agrava la responsabilidad del estado frente a estas gravísimas violaciones a los derechos humanos. Además, se hace más evidente más que nunca la obligación estatal de maximizar la eficiencia en las búsquedas. La restitución de la identidad de los hoy jóvenes adultos apropiados es la única manera de restablecer plenamente el derecho conculcado, y la más eficaz para la reparación de los daños producidos y hacer desaparecer los efectos de las violaciones. La modernización del Banco Nacional de Datos Genéticos a casi dos décadas de su creación por ley apunta a cumplir con estas obligaciones estatales. (Carlotto, 2006)

Los diputados de los partidos UCR y ARI presentaron al año siguiente un proyecto de ley, refutando los argumentos propuestos para la creación de un banco circunscripto a delitos de lesa humanidad. Según la diputada Alicia Tate, el BNDG del Hospital Durand cumplía con sus funciones y requerimientos para la identificación de hijos de desaparecidos:

Tanto el señor diputado Carlotto como la directora de la Comisión Nacional por el Derecho a la Identidad [Conadi], Claudia Carlotto, y la presidenta de la Asociación Abuelas de Plaza de Mayo, Estela de Carlotto, manifestaron [...] que [...] el rol del banco se fue tergiversando y pasó a ocuparse más de datos de filiación que de aquellos vinculados con la resolución de identidad de los niños apropiados o nacidos en cautiverio durante la dictadura militar, incurriendo incluso en demoras de hasta un año y ocho meses en responder a los requerimientos de la Conadi. Esto es absolutamente inexacto ya que en ningún momento en el Banco Nacional de Datos Genéticos se postergó la realización de los estudios solicitados en relación con las causas mencionadas; siempre se respondió con la debida celeridad, que por supuesto ha ido variando de acuerdo con los avances tecnológicos. (Diputada Tate en HCDN, 2006)

El proyecto 5899-D-2006 fue tratado en sesión plenaria de la Cámara de Diputados y no prosperó ${ }^{9}$. Según diversas fuentes, el proyecto de ley no

9 Los legisladores firmantes fueron los diputados del partido gobernante, Frente Para Victoria, Remo Carlotto, Aracely Méndez, Diana Conti, Rosario Romero, Agustín Rossi, Juliana 
generaba consenso ni dentro del partido que lo proponía, ni entre los organismos de DD. HH. Las fuentes señalan que el director del Centro de Estudios Legales y Sociales, Horacio Verbitsky, envió una carta a los legisladores manifestando disidencias con el proyecto, en particular en su establecimiento en el marco de la Secretaría de DD. HH. de la Nación, situación que, indicaban, comprometería su imparcialidad. La disidencia oponía la autonomía histórica del BNDG, que desde sus orígenes oficiaba como perito-técnico de la justicia, a la dependencia política que suponía subordinarse a la Secretaría de DD. HH. Tal dependencia supondría no solo que el secretario a cargo pasaría a ser el responsable de la designación del director o directora del BNDG, sino también un problema para garantizar la imparcialidad en los juicios, si se consideraba que, en muchos casos, la secretaría actuaba como querellante en las causas de lesa humanidad de apropiación de niños y niñas ${ }^{10}$.

Desde los partidos de izquierda también se manifestaron en contra del traslado del BNDG con actividades, audiencias públicas en la legislatura de la Ciudad de Buenos Aires y movilizaciones denominadas "TodosxelBanco" y "Por la universalización del derecho a la identidad". En estas actividades participaron, además, representantes de organismos de DD. HH., como Nora de Cortiñas, Elia Espen, Adolfo Pérez Esquivel, Elsa Pavón, Néstor Carlini, Marcela Gudiño, Pablo Pimentel y asociaciones de víctimas de violencia institucional en democracia, como Familiares y Amigos de Luciano Arruga ${ }^{11}$.

Así, coyunturalmente, las iniciativas de creación del INDG surgían en un contexto de diversificación de funciones del BNDG que, a su vez, implicaba la participación de nuevos actores y demandas que se alejaban del origen fundacional ligado a las violaciones a los derechos humanos cometidas durante la dictadura. Sin embargo, estas iniciativas

Di Tullio, Amelia López, Graciela Rosso, Nora César, Carlos Kunkel y Ana Monayal. Del Socialismo adhirió Hermes Binner y del Partido Convergencia, Miguel Bonasso.

10 Véase Expediente 5634-D-2007, García Mendez, líneas 23 y ss.

11 Véase Anred, "Mirta Baravalle: El Banco de Datos Genéticos del Hospital Durand es irremplazable", 21 de junio de 2014 Luciano Arruga fue un joven de 16 años que desapareció a fines de enero de 2009 luego de ser detenido por la policía de la Provincia de Buenos Aires. Para octubre de 2014 su cuerpo apareció en una tumba sin identificación (N.N.) de un cementerio de la Ciudad de Buenos Aires. Por el caso fueron condenados integrantes de la policía bonaerense. eran vistas por diversos legisladores, sectores de los organismos de derechos humanos y familiares de otros colectivos de víctimas como una medida que restringía el derecho a la identidad y comprometía la imparcialidad del trabajo científico-técnico. La coyuntura ponía en evidencia el carácter plural y heterogéneo del activismo de las víctimas, los procesos de diversificación de sus demandas y las tensiones existentes, tanto entre como en el seno de los diversos colectivos emergentes. Estas tensiones se manifestaban aun en los casos de familiares unidos por una experiencia común de victimización y solidarios de la misma causa, como sucedía entre las asociaciones de familiares de víctimas del terrorismo de Estado.

Finalmente, el proyecto del traslado del BNDG se terminó de discutir en el año 2009. En esa nueva ocasión, la iniciativa de Remo Carlotto (5899-D2006) fue retomada y propuesta directamente por la presidenta de la Nación, Cristina Fernández de Kirchner. En una misiva entregada a los legisladores, la presidenta recuperaba el relato de memoria que indicaba que el BNDG fue establecido para dar respuesta a los reclamos de las Abuelas de Plaza de Mayo en la búsqueda de sus nietos y que esta debería ser su función específica ${ }^{12}$. Además de incorporar una actualización en las técnicas de análisis de ADN, el proyecto de ley incluyó como novedad la intervención en antropología forense para la identificación de restos óseos recuperados de tumbas clandestinas y su resguardo en un archivo. De esta manera, el BNDG comenzaría a intervenir también en tareas que estaban vinculadas al Equipo Argentino de Antropología Forense ${ }^{13}$.

Así como se recuperó el proyecto de ley de Carlotto (5899-D-2006) también se retomaron los argumentos a favor y en contra del traslado del BNDG que habían surgido durante su discusión en el año 2006. A estos argumentos se sumaron en el nuevo escenario otros dos en contra del traslado. El primero, vinculado al rol de las autoridades del BNDG establecido en el artículo 19: "la responsabilidad y dirección de un (1) director general técnico, profesional en bioquímica o biología molecular, con reconocida experiencia en genética forense, un (1) subdirector técnico, con igual profesión y especialización". En la ley se indicaba que estos

12 Véase PEN, Expte. 1241/09, p. 2.
13 Véase PEN, Expte. 1241/09, p. 5. 
cargos serían designados por el Poder Ejecutivo Nacional mediante un concurso público, pero, a su vez, se restringía el cargo a los biólogos, excluyendo a los médicos, antropólogos, u otros profesionales vinculados a la genética. Esto generaba gran rechazo entre un grupo importante de legisladores (HCSN, 17a reunión, 13a sesión ordinaria, 18 de noviembre de 2009). El segundo aspecto señalado como argumento para el rechazo del traslado del BNDG se relacionaba con el periodo histórico que abarcaría el banco para el registro de sus muestras. Según el artículo 2 de la ley finalmente sancionada (26.548), el objeto del banco era el esclarecimiento de delitos de lesa humanidad ejecutados en el ámbito del Estado hasta el 10 de diciembre de 1983. Esto generaba controversias porque dejaba afuera las ejecuciones extrajudiciales cometidas por el Estado, encarnado en sus fuerzas de seguridad, en el periodo democrático:

Qué terrible que debamos oír que si nos toca identificar a Julio López ${ }^{[14]}$, lo hagamos en un laboratorio privado o "nos creemos otro banco". [...] ¿A dónde podrán acudir en caso de querer comprobar su identidad biológica las más de cien personas que acuden por año a la Oficina de Derechos Humanos del Registro Civil de la Ciudad de Buenos Aires? ¿Con qué instrumento contarán quienes, como la hermana Martha Pelloni, intentan poner fin al tráfico de niños y niñas? (Fernanda Gil Lozano en HCDN, 2009, periodo 127, reunión 15, p. 135)

En la Cámara de Diputados el proyecto de ley del BNDG fue aprobado, con la modificación de su establecimiento como ente autárquico en el Ministerio de Ciencia y no en el de Justicia, como se pretendía originalmente. Luego, el proyecto pasó para discusión en la Cámara de Senadores, que terminó de aprobar la ley en su reunión del 18 de noviembre de 2009. Las exposiciones en el debate legislativo dejan entrever que entre los distintos bloques se anticipaba que lograr el consenso para aprobar el traslado y constitución del BNDG, como ente autárquico y circunscripto a la investigación de crímenes de lesa humanidad, conllevaba al tratamiento posterior de

14 Jorge Julio López fue una víctima de desaparición forzada de la última dictadura militar. Como sobreviviente, fue convocado para declarar como testigo en juicios de lesa humanidad, particularmente en el que fue condenado a prisión perpetua el represor Miguel Etchecolatz. Luego de declarar en ese juicio, el 18 de septiembre de 2006 fue desaparecido por segunda vez y aún se desconoce su paradero. una ley para un registro especial para delitos sexuales. Esta reducción del objeto del BNDG dejaba sin protección un conjunto de muestras genéticas que hasta entonces albergaba y sin horizonte a otras víctimas que clamaban justicia.

Así se expresaba, Pichetto, quien venía presentando proyectos sobre bancos de ADN, como vimos, desde 1998:

Empieza [...] una tarea que hay que llevar adelante entre todos [...] la conformación de un banco que sea eficiente [...] para identificar casos de identidad no resuelta, de dudas, de controversias en el tiempo, de chicos que a lo mejor fueron secuestrados por la dictadura. Pero, también, para identificar a delincuentes, asesinos seriales, violadores, que en la Argentina no se pueden identificar todavía y que forman parte de un clamor de muchas entidades, como las Madres del Dolor y de gran cantidad de ciudadanos que reclaman justicia frente a chicas que han sido violadas y asesinadas. (Senador Pichetto en HCSN, 2009, 17a reunión, 13a sesión ordinaria, pp. 78-79)

El tratamiento legislativo incluyó además la discusión sobre el artículo 218bis del Código Procesal Penal, que indica que "el juez podrá ordenar la obtención de ácido desoxirribonucleico (ADN), del imputado o de otra persona, cuando ello fuere necesario para su identificación o para la constatación de circunstancias de importancia para la investigación". La cuestión de la toma de muestras compulsiva, la posibilidad de negarse a brindar ADN y su obtención por medios indirectos generaban posiciones encontradas entre los distintos legisladores. Los argumentos giraban en torno a la diferencia entre tipos de delitos (comunes y de lesa humanidad) y sujetos de la extracción compulsiva (víctimas e imputados).

La mayoría de los senadores se mostraba de acuerdo en la extracción del ADN para imputados de todo tipo de delitos y manifestaba que el resguardo de sus derechos estaba garantizado porque la redacción del texto del artículo dejaba a criterio de los magistrados la obligatoriedad o no de la extracción de la muestra (HCSN, 2009, 17aㅡ reunión, 13a sesión ordinaria). Asimismo, había consenso en la toma de muestras de ADN por vías indirectas, cuando la extracción directa no fuera posible, principalmente, 
para no revictimizar, con los procedimientos de la investigación judicial, a las víctimas de delitos en caso de que se negasen a dar su muestra para análisis de ADN. Algunos legisladores manifestaban preocupación por los procedimientos de extracción de ADN que, de acuerdo al artículo 1 de la Ley 26.549, habilitaba el "uso de las facultades coercitivas sobre el afectado", sin precisar el límite de lo considerado "estrictamente necesario para su realización". Bajo esa precaución se manifestaba el senador Petcoff Naidenoff.

¿Cuál es el límite de la acción punitiva del Estado para el imputado o para otras personas? Ese es el derecho que está en pugna ¿Cuál es el límite? [...] El imputado es reconocido por el nuevo sistema constitucional como [...] una persona humana, la que se valoriza en su dignidad. De allí que se le reconozcan derechos como tal, y se los proteja aun durante el proceso penal. (HCSN, 2009, 17aㅡ reunión, 13aㅡ sesión ordinaria, pp. 46-47)

Si bien los partidos habían expresado que iban a votar afirmativamente esta reforma, algunos de sus legisladores manifestaban las controversias que se generaban en torno al tratamiento de los imputados por delitos penales:

Miren qué paradoja: en el caso de las víctimas de delitos de lesa humanidad, se les permite negarse a la extracción compulsiva, cuando es precisamente en ese caso donde ellos no son sujetos de prueba porque no son imputados, sino donde su cuerpo es objeto de prueba. $Y$ al ser su cuerpo objeto de prueba, lo que rige, lo que prima, es que ese cuerpo tiene que estar al servicio de un interés superior, cual es la verdad real. Pero aquí, en este caso, le estamos dando la posibilidad de que se nieguen. En el otro caso, en el de los imputados de delitos comunes, actuamos al revés: allí, cuando el cuerpo es sujeto de prueba y donde rigen todas las garantías de la inviolabilidad de la defensa en juicio y de no declarar en contra de sí mismos, la redacción es amplia y donde no hay negativa: ahí está la extracción compulsiva. (Senador Sanz, 2009, HCSN, 17ạ reunión, 13a sesión ordinaria, p. 76)

Esta tensión de la condición humana común entre víctimas de delitos de lesa humanidad e imputados de delitos comunes y la distinta naturaleza de los delitos en juego se convierte en el nudo gordiano de la justificación de la división del trabajo en materia de biobancos nacionales. Por ende, una vez circunscripto el BNDG, parece imponerse para los legisladores la necesidad de dar creación al RNDG. Por otra parte, el tratamiento conjunto de la reforma del artículo 218bis del Código Procesal Penal, que facultaba al juez para extracción compulsiva de ADN para todo tipo de delitos, hacía explicita la vacancia:

Creemos también que es correcto que esto se implemente en todos los casos en que se esté investigando un delito, porque este es un método [...] que permite la investigación criminal de manera certera [...] Se trata de una metodología acreditada fundadamente y es casi un elemento imprescindible que se complementa con el banco de datos. Si no tenemos el banco de datos nos va a faltar una herramienta central, que es la posibilidad de obtener el ADN y compararlo. (Senador Pichetto, 2009, HCSN, 17ạ reunión, $13^{a}$ sesión ordinaria, p. 78)

Finalmente, la ley de reforma del Código Procesal Penal se sancionó el 18 de noviembre de 2009. Fue resultado no solo del consenso general de los partidos y de la necesidad de brindar herramientas para la investigación judicial, sino para dar un marco de legalidad a una práctica ya frecuente en los tribunales y, a su vez, adecuar la norma a la doctrina de la Corte Suprema de Justicia de la Nación en los casos de delitos de lesa humanidad, a raíz de los fallos conocidos como Prieto I y Prieto II $^{15}$.

Su promulgación fue inmediatamente seguida de la presentación de medidas judiciales por parte de imputados por delitos sexuales que se resistían a otorgar sus muestras de sangre aduciendo violación al derecho a la intimidad, a la integridad personal y al derecho de no declarar contra sí mismo. Aunque la controversia, en materia de garantías procesales, acerca de constituir al propio cuerpo como una carga acusatoria para la persona imputada sobrevoló durante el debate ${ }^{16}$, el consenso generalizado en el ámbito legislativo fue el de privilegiar el derecho a la verdad (jurídica por parte de las víctimas y la sociedad en su conjunto) por sobre otros:

15 Se trata de sentencias que establecieron pautas de obtención de ADN para presuntos hijos de desaparecidos durante la última dictadura militar. Ver http://catedradeluca.com.ar/ wp-content/uploads/2015/01/gualtieri-rugnone-de-prieto.csjn.-2-.pdf -.html. Véase Anitua (2011).

16 Véase Senador Pérez Alsina, 2009, HCSN, 17ạ reunión, 13ạ sesión ordinaria, p. 60. 
La ciencia y la tecnología también nos ayudan en la búsqueda de la verdad, pero no solamente en los crímenes de lesa humanidad cometidos contra los desaparecidos en la dictadura militar más horrorosa que hemos tenido, sino en otros hechos aberrantes que son bastante frecuentes, como el abuso a la sexualidad de los niños, de las niñas, de las mujeres, la desaparición de personas. (Senadora Corregido en HCSN, 2009 17ạ reunión, 13aㅡ sesión ordinaria, p. 58)

Los debates de la Ley 26.548, que volvía exclusivo al BNDG para esclarecimiento de delitos de lesa humanidad, y de la Ley 26.549, artículo 218 bis Código Procesal Penal, sobre extracción de muestras de sangre para análisis de ADN, dieron el paso a la discusión de una ley propia para el Registro Nacional de Datos Genéticos vinculados a Delitos contra la Integridad Sexual. Este registro, que funcionaría en el ámbito del Ministerio de Justicia y Derechos Humanos de la Nación, fue creado por Ley 26.879 en el año 2013, reglamentado por decreto del Poder Ejecutivo Nacional en 2017 (Decreto 522/2017) y fue aprobado con amplio consenso en ambas cámaras legislativas.

Como vemos, la creación de dos biobancos en el ámbito estatal permitió distinguir entre muestras biológicas para restituir derechos a las víctimas y muestras biológicas para inculpar o exculpar a imputados de delitos comunes y almacenarlas por separado. A su vez, la división del trabajo, conforme se tratara de delitos comunes o de lesa humanidad, se situó en distintas esferas estatales: el Ministerio de Justicia y el de Ciencia y Tecnología, respectivamente. Sin embargo, esta sensibilidad para administrar distintos tipos de muestras biológicas no rigió a la hora de contemplar las diversas garantías ciudadanas que protegen a sujetos enfrentados en un mismo proceso judicial: víctimas e imputados. Fue, en cambio, vehículo de jerarquización de derechos fundamentales: el derecho a la verdad se erigió como el fundamento de la justicia para establecer un mandato procesal común: la extracción compulsiva de ADN. En el mismo proceso, al designar a los biólogos como los profesionales adecuados para la dirección del BNDG, el Estado definió competencias en el campo científico, legitimando algunos capitales expertos por sobre otros para la construcción de la "verdad jurídica".

\section{Registro de datos genéticos vinculado a delitos contra la integridad sexual: "el derecho de las víctimas a la verdad" (2009-2017)}

En el año 2010, el Senador Ramón Mestre, de la UCR, recuperando la tradición legislativa iniciada a fines de los años noventa en materia de bancos de datos genéticos de ofensores sexuales, presentó un proyecto de ley (Expte. S3370/2010) para crear un registro especial de delitos contra la integridad sexual. En los fundamentos, Mestre situaba al proyecto en la tradición inaugurada por Pichetto, entre otros $^{17}$. A estos antecedentes, se sumaban los siete proyectos presentados — sin resultados - por el diputado nacional por la provincia de Salta, Alfredo Olmedo, que proponía un registro de ADN para toda la población argentina ${ }^{18}$. La fundamentación esgrimía como argumentos centrales el "avance en todos los estratos sociales de los delitos contra la integridad sexual", "la repercusión que estos hechos producen en la comunidad", "la movilización de organizaciones no gubernamentales de víctimas" que activan (Mestre en HCSN, S3370/2010, pp. 3-4). El objetivo de este proyecto era además, como los precedentes, que el registro incluyera una fotografía de procesados y condenados y que se estas plasmaran en una página web de dominio público. Con distintas variaciones, el día de la discusión parlamentaria fueron tratados los proyectos, además del de Mestre ${ }^{19}$. El texto definitivo, finalmente sancionado en Cámara de Senadores el 31 de agosto de 2011, incluía la elaboración de dos bases de datos genéticos: una para condenados con sentencia firme (individuos identificados) y otra para muestras de individuos no identificados, recolectadas en escenas del crimen. En cambio, dejaba afuera la cuestión de la publicidad de los datos, aunque sí contemplaba la incorporación de una fotografía y otras informaciones de los condenados ${ }^{20}$. Asimismo, el texto de

17 Véase, HCSN, S3370/2010, pp. 3-4.

18 Véase Olmedo, 2013, HCDN 131, periodo Ordinario, 6a sesión, 8aㅡ reunión, p. 99.

19 Entre ellos, los de Pichetto que, con distintas variaciones, proponían la creación de un Registro Especial para los Delitos de Abuso Sexual y la de un Registro Nacional de Identificación Genética de Abusadores Sexuales; los de la senadora Sonia Escudero que planteaban la creación de un Registro Nacional de Datos Genéticos vinculados a delitos contra la integridad sexual y el de senador Romero que se orientaba por la creación del Registro Nacional de Identificación de Abusadores Sexuales.

20 Según el artículo 3, se solicitaba nombre y apellido, apodos o seudónimos, fotografía actualizada, fecha y lugar de 
la ley indicaba que los datos y las muestras serían guardados por cien años (art. 10), considerando a estos delitos como imprescriptibles.

Los senadores destacaban que estos proyectos ya se habían discutido en reiteradas oportunidades en la Cámara de Senadores y que, aunque lograban media sanción, luego no prosperaban. Asimismo, relataban que tanto familiares de las víctimas, como Isabel Yaconis, presidenta de la asociación Madres del Dolor, como expertos en genética y derecho, habían participado como asesores ${ }^{21}$. Los legisladores mencionaban además que al menos once provincias del país ya contaban con registros de datos genéticos y que era necesario sancionar una ley nacional para regular esta cuestión en todo el territorio ${ }^{22}$. También manifestaban un amplio consenso y acuerdo entre las fuerzas políticas, especialmente en el Senado, aunque temían por los "ultragarantistas" de la Cámara de Diputados que rechazaban siempre ley de registro de ofensores sexuales ${ }^{23}$. Para Pichetto, el largo derrotero del debate legislativo del registro de ofensores sexuales iniciado en 1998 se debía a ese "ultragarantismo" que tenía eco en un conjunto de jueces. Desde entonces, inspirado en el modelo norteamericano y en el sostenido activismo de las organizaciones de víctimas, había impulsado incansablemente lo que consideraba "un decisivo avance" hacia la modernización del país en materia de investigación criminal, a tono con la agenda internacional:

Los americanos, por supuesto, con el presidente Clinton a la cabeza, Ilevaron esta iniciativa al Congreso y la sancionaron. Se denominó "ley Megan", y planteaba el registro de datos de ADN para identificar a los violadores. Ellos trabajaban también sobre el perfil y el modus operandi del violador. Pero eso ya es demasiado en la Argentina, por ahora. Indudablemente, va a tener que pasar todavía un poco más de tiempo y, lamentablemente, algunos hechos más graves para que avancemos en tal sentido. (Pichetto, en HCSN, 2011, 10ª reunión, 8aㅗ sesión ordinaria, p. 63)

nacimiento, nacionalidad, domicilio actualizado.

21 Véase HCSN, 2011, 10ª reunión, 8ª sesión ordinaria, p. 60.

22 Las provincias que contaban con legislación y habían constituido sus bancos de datos para delitos sexuales en el año 2011 eran Córdoba, Buenos Aires, Santa Fe, Corrientes, Chubut, San Luis, La Pampa, San Juan, Santa Cruz, Mendoza y Chaco (HCSN, 2011, 10 ํa reunión, 8ª sesión ordinaria).

23 HCSN, 2011, 10ª reunión 8ª , sesión ordinaria, p. 60.
El proyecto fue sancionado por unanimidad con "aplausos en las galerías" del recinto legislativo, donde se encontraban diversas asociaciones de familiares de víctimas presenciando el debate ${ }^{24}$. Luego de esta sanción en senadores, fue derivado a la Cámara de Diputados y se discutió en la reunión el 3 de julio de 2013 en la $8^{\circ}$ reunión del 131 periodo ordinario, 6aㅗ sesión. Con argumentos similares a los esgrimidos en el Senado, el proyecto tuvo un voto negativo, doscientos once afirmativos y cuarenta y cinco diputados ausentes ${ }^{25}$.

Además del consenso generalizado en el ámbito legislativo, los diputados destacaban la labor activista de los familiares de víctimas de delitos sexuales y la capacidad de concertación de la entonces presidenta Cristina Fernández de Kirchner para la aprobación del RNDG, anteponiendo el derecho a la verdad de las víctimas a la propia adhesión a la tradición garantista:

Este instrumento es fruto de la militancia de las víctimas y de los familiares de quienes padecieron estos aberrantes delitos, de su esfuerzo y perseverancia para ir convenciéndonos uno a uno de que cediéramos en ese dogmatismo para validar la utilidad de este instrumento. La presidenta de la Nación los reunió, la convencieron en cinco minutos y ordenó al jefe de Gabinete y al Ministerio de Justicia que nos instaran a deponer paradigmas dogmáticos en función de un instrumento que nos permite decir "no" a los violadores y asesinos. (Diputada Conti, 2013, HCDN, 131 periodo ordinario, 6a sesión, 8a reunión, p. 82)

Solo un legislador, Manuel Garrido, proveniente del campo jurídico, manifestó desacuerdo con el texto de la ley, indicando que se estaba legislando bajo el presupuesto de que los delitos sexuales tenían alta tasa de reincidencia, cuando la evidencia estadística indicaba lo contrario. Según consignaba, solo se registraba el $8 \%$ de reincidencia en este tipo de delitos versus el $44 \%$ existente en delitos contra la propiedad, el $22 \%$ en tráfico de estupefacientes y $19 \%$ en delitos contra las personas. Además argumentaba que el registro de las muestras

24 HCSN, 2011, 10ª reunión 8ª , sesión ordinaria, p. 65.

25 Véase, por ejemplo Diputado Albrieu, 2013, HCDN, 131 periodo ordinario, $6^{\underline{a}}$ sesión, $8^{\underline{a}}$ reunión, p. 81. 
por cien años era anticonstitucional ${ }^{26}$. Otro de los argumentos, que exponía Marcela Rodríguez, la única legisladora que votó en contra, sostenía que tal registro era contrario a la lucha histórica del movimiento feminista:

Las violaciones a las mujeres no se inscriben en una lógica de inseguridad; se inscriben en una lógica de opresión, discriminación, jerarquía entre los géneros y violencia contra las mujeres Aunque existe un subregistro y una invisibilidad de las cifras, más del 71 por ciento de las agresiones sexuales denunciadas corresponden a agresores conocidos: familiares, esposos, novios, amigos, compañeros de trabajo [...] Cuando las mujeres nos animamos a denunciar conocemos a nuestros agresores, podemos decir: fue tal persona, pero el problema es que ni siquiera nos creen. ¿Ahora además se va a requerir una muestra genética para que nos crean? (Diputada Rodríguez, en HCDN, 2013, 131 periodo ordinario, 6a sesión, $8^{\mathrm{a}}$ reunión, p. 85)

La intervención es elocuente porque pone en evidencia la prevalencia del valor de la prueba biológica por sobre otro tipo de saberes, como el históricosociológico que permite poner otras evidencias sobre la mesa. A su vez, deja entrever la disputa entre distintas formas de activismo de las víctimas, contraponiendo en este caso las asociaciones de familiares a la lucha de las mujeres. Esta fue, sin embargo, una voz minoritaria y primó, en cambio, el acuerdo con la creación del registro. Consideraban que no era la solución a la violencia sexual contra las mujeres, pero que era una herramienta útil, incluso, a pesar de haber cobrado fuerza de un proceso de "blumberización", de los debates legislativos en cuestiones penales antes referidos, desde el año 2004 en adelante ${ }^{27}$. El proyecto de ley fue aprobado también con aplausos de los propios legisladores y los familiares de víctimas y se inscribía en una serie de leyes que se dirigían al control de los ofensores sexuales. Un año antes, se había derogado la figura del "avenimiento" (Ley 26.738) ${ }^{28} 30$ y, a su vez, se

26 Garrido, 2013, HCDN, 131 periodo ordinario, 6aㅗ Sesión, 8aㅗ reunión, p. 83.

27 HCDN, 2013, 131 periodo ordinario, 6aㅗ sesión, 8aㅡ reunión, p. 93.

28 Se trata de una figura hasta entonces vigente en el Código Penal, por medio de la cual la víctima de un delito sexual podía solicitar un "perdón" para el victimario y, de este modo, extinguir la acción penal, siempre y cuando lo hiciera había aprobado "la ley Bargna", redactada por los diputados Diana Conti y Carlos Kunkel, que modificaba la ley de ejecución penal 24.660, Ilamada así en conmemoración de Soledad Bargna, una joven que fue violada y asesinada por un condenado por delitos sexuales durante sus salidas transitorias. Por medio de esta modificación se eliminaba el periodo de prueba previo a la libertad condicional, es decir, las salidas transitorias para delitos considerados graves.

El establecimiento del RNDG por ley fue reglamentado recién en el año 2017, durante la presidencia de Mauricio Macri, con argumentos análogos a los esgrimidos por Cristina Fernández de Kirchner:

Que el propósito de afianzar la justicia enunciado en el Preámbulo de la Constitución Nacional, exige sin dudas la adopción de los mecanismos que permitan identificar y condenar a los autores de los delitos, a lo que se suma el derecho a la verdad consagrado por la Comisión Interamericana de Derechos Humanos, que consiste en un derecho elemental de la víctima, que impone la necesidad de arbitrar los medios para posibilitar el esclarecimiento de los hechos delictivos ocurridos en nuestra Nación. (Poder Ejecutivo Nacional-PEN, Decreto 522/17)

De este modo, la creación y reglamentación del RNDG generaba un consenso que trascendía las ideologías político-partidarias, anteponiendo el derecho a la verdad de las víctimas y de sus familiares por sobre otros derechos ciudadanos. En este acto, la figura de la víctima devenía en la encarnación del "ciudadano pleno", es decir, "reforzaba la necesidad de mostrarse como víctima para ser reconocido como ciudadano" (Gatti y Martínez, 2017, p. 10) y justificaba la adopción de un paradigma de justicia penal basado en el derecho a la verdad de las víctimas de delitos comunes. En este decurso, siguiendo a Catoggio (2019a), el ADN devenido a partir de los años ochenta en "régimen de verdad" para los familiares de las víctimas de delitos de lesa humanidad ganaba terreno en nuevas áreas del campo del derecho y, en términos de Barrera (2012), se abría camino como "dispositivo de certeza e infalibilidad" en el discurso judicial.

de forma libre y sin presiones. Véase Ley 25087, art. 15, 7 de mayo de 1999. 


\section{El Registro Nacional de Datos Genéticos vinculados a delitos contra la integridad sexual en perspectiva global}

En los debates legislativos, tanto en Cámara de Senadores como en la de Diputados, se justificaba la normativa sancionada en relación a los datos genéticos, mayoritariamente, como una necesidad para dar respuesta a las víctimas y a sus familias y para condenar a autores de delitos "aberrantes", considerados un "peligro para la sociedad"29. Se legislaba en función de la necesidad de dar respuesta a los reclamos sociales ante crímenes que causan conmoción social con la presencia de organizaciones de familiares de víctimas en las galerías de la sala de reuniones. Sin embargo, algunos legisladores mencionaban que la agenda internacional y requerimientos de organismos transnacionales también incidían o generaban una cierta presión para que el país se adecuara a estándares de investigación judicial y forense internacionales.

Los 76 países miembros de Interpol hoy han implementando o están implementando bases de datos de ADN [...] Y lo otro que es fundamental, en especial para lo que es persecución de delitos y rastreo de víctimas de trata, es contar con un banco o un registro que pueda firmar convenios internacionales, porque muchos de estos delitos son de origen transnacional. Entonces, por favor no esperemos otra década más para tratar de conseguir herramientas que ayuden a facilitar la seguridad de los ciudadanos. (Diputada Schmidt Liermann en HCDN, 2013, 131 Periodo Ordinario, $6^{\underline{a}}$ sesión, $8^{\underline{a}}$ reunión, p. 95)

En general, quienes mencionaban las experiencias de otros países las comunicaban a los demás legisladores como exitosas en la persecución penal de delincuentes, a excepción de la diputada Rodríguez, la única que había votado en contra de la ley, que comentaba la ineficacia de estos registros:

Esto se ha defendido diciendo que se ha puesto en práctica en otros países y ha funcionado. Se ha dicho acá que esto es eficaz. La verdad es que esto no es así. Los ejemplos que se han mencionado de Francia, Inglaterra, Estados Unidos y Australia no han servido para tener

29 HCSN, 2011, 10ª reunión, 8aㅗ sesión ordinaria; HCDN, 2013 , 131 periodo ordinario, $6^{\underline{a}}$ sesión, $8^{\mathrm{a}}$ reunión. impacto en un mayor número de condenas o convertirse en una herramienta disuasoria, y lejos de ser auspiciosos en algunos casos hasta ha bajado la tasa de condenas. (Diputada Rodríguez, HCDN, 2013, 131 periodo ordinario, 6 $6^{\underline{a}}$ sesión, 8aㅡ reunión, p. 85)

Siguiendo a McCartney, Wilson y Williams (2011), la agenda internacional en el área forense, que instaba a los países a adecuarse a estándares que posibilitasen el intercambio de información, también se colaba en la disputa por la utilización de un software común a escala global para la recopilación de la información genética. Aunque dieciocho provincias de Argentina habían manifestado su interés por utilizar un software desarrollado localmente (GENis), el gobierno de Mauricio Macri rubricó un convenio con FBI de Estados Unidos para que el país adoptase el CoDIS ${ }^{30} .32$ Desarrollado y mantenido por el FBI, este software permite administrar y establecer correlaciones a partir de la información de los bancos de datos de ADN locales, provinciales y nacionales de perfiles de ADN de personas condenadas, de pruebas halladas en la escena del crimen y de personas desaparecidas. Como demuestran Osborn-Gustavson, McMahon, Josserand y Spamer (2018), se trata de una tendencia de creación de registros nacionales de ADN, basada en la coordinación de estrategias de almacenamiento y análisis de datos genéticos con la utilización del software CoDIS que se afirma en la región y ya ha sido adoptada por cincuenta países en el mundo. La dimensión trasnacional del crimen esbozada por los legisladores justifica y exige la adecuación a estándares internacionales para la recopilación y análisis de la información genética, que tiene proyecciones globales sobre nuevos grupos de población.

En las últimas décadas se ha producido un incremento del uso forense de información almacenada en bases de datos de genealogía, cuyo ejemplo emblemático es el caso GEDmatch y el "asesino del Golden Gate" ${ }^{\prime \prime 1}$. Desde principios de la década del 2000, diversas unidades policiales comenzaron

30 Véase La Nación, "18 provincias usarán software local para el registro nacional de violadores, pero siguen las demoras", 8 de marzo de 2018.

31 Nos referimos al caso de California, en Estados Unidos, donde la policía arrestó en 2018 a James De Angelo, sospechoso de ser el célebre "Golden State Killer", que había aterrorizado a la población durante cuarenta años, gracias al uso GEDmatch, una base de datos pública en donde están los resultado de empresas de pruebas genéticas como 23andMe o Ancestry, 
a identificar a autores de delitos a partir de la búsqueda de ADN de familiares en Inglaterra y Estados Unidos, y su uso se ha extendido en los países europeos, norteamericanos y asiáticos, como demuestran Suter (2010), Roberts (2011) y Maguire et ál. (2014). Considerando que la información de un individuo, cuya huella genética está almacenada en una base de datos, brinda información sobre sus parientes cercanos, según Suter (2010) las autoridades policiales de diversos Estados comenzaron a establecer mecanismos de vigilancia a familias hasta dar con los autores de los delitos. Así, como sostiene Roberts (2011), los bancos de datos ya no solo permiten detectar sospechosos, sino que los crean al poner en vigilancia a un grupo de personas por asociación genética con el imputado de algún delito, generando procesos complejos de control social. A su vez, por mecanismos que Zaffaroni (2009) denomina "de criminalización primaria y selectividad del derecho penal", las bases de datos que almacenan información genética para investigaciones judiciales tienen sobrerrepresentación de poblaciones vulneradas, dando lugar a estigmatizaciones con base biológica y a violaciones de los derechos humanos.

De acuerdo con Roberts (2011) y Kwong (2017), a pesar de que los especialistas sostienen que los análisis de ADN son complejos, dependen de la correcta toma de las muestras durante la etapa de investigación judicial y de la subjetividad del análisis propia del método científico; estas técnicas y procesos cuentan con una elevada credibilidad ante la opinión pública. La difusión de casos en la prensa y en el ámbito del cine, la literatura y la televisión han contribuido a consolidar la confianza de los ciudadanos con relación a las potencialidades de los análisis de ADN para la identificación objetiva de individuos y para el establecimiento de la culpabilidad o inocencia ante la imputación de un delito. Los decisores de políticas públicas esgrimen también confianza en estas tecnologías y proponen proyectos legislativos que amplíen las colecciones de muestras genéticas de las poblaciones a nivel nacional tanto para cuestiones de salud pública (medicina de precisión) como para la investigación de delitos.

que permiten encontrar a familiares haciendo ingeniería inversa de sus árboles genealógicos.
Este escenario de utilización creciente del ADN como método de certeza e infalibilidad en la investigación judicial abre un panorama sombrío para el campo de los derechos humanos en la Argentina, si se repite la tendencia mundial que comienza por la creación de registros de ofensores sexuales para luego continuar con la totalidad de la población.

\section{CONCLUSIONES}

La creación del Banco Nacional de Datos Genéticos en 1987 inicia un ciclo en materia de una política estatal de genética y derechos humanos que se concluye entre 2013 y 2017 con la creación y reglamentación del Registro Nacional de Datos Genéticos Vinculados a Delitos contra la Integridad Sexual. El análisis realizado, a partir de los debates legislativos, nos permitió mostrar los hilos comunes de ambos procesos, a pesar de la distancia temporal entre ellos. Los acuerdos y controversias en torno a la creación de ambos biobancos formaron parte de una discusión común: cómo articular desde el Estado la utilización de técnicas de ADN al servicio de los derechos humanos, conforme la diversificación de demandas del activismo de las víctimas y las crecientes exigencias internacionales de estandarización de estas técnicas para la investigación judicial. La solución que se impuso fue el proceso de diferenciación y división del trabajo que llevó a la creación de dos bancos separados para responder, a la vez, a distintos colectivos de víctimas, sin desentonar con las exigencias internacionales. Por un lado, se reservó al BNDG para las muestras biológicas de familiares y víctimas de la última dictadura militar para avanzar en los procesos de restitución de la identidad de las hijas e hijos sustraídos durante la última dictadura militar y estrechar los mecanismos de colaboración con el trabajo de la genética forense de identificación de restos humanos. Por el otro, se creó al RNDG como un banco destinado a albergar muestras biológicas eficaces para determinar huellas genéticas que permitan condenar o absolver a imputados por delitos sexuales. La extracción de ADN compulsivo se resolvió como mecanismo igualitario de distintos actores enfrentados en un mismo proceso judicial: víctimas e imputados. En nombre de la "verdad de las víctimas", se refuerza la figura del "ciudadano-víctima". Como vimos, lejos de ser un campo homogéneo, el mundo de las víctimas está compuesto por distintas organizaciones de familiares o afectados en primera persona cuya movilización va más allá del dolor y supone una disputa por el sentido social y político de las causas 
emprendidas. En ese sentido, durante treinta años no solo asistimos a un proceso de diversificación de demandas por parte del activismo de las víctimas, sino también de proliferación de colectivos diversos no siempre coincidentes.

En el derrotero analizado, en el caso del BNDG la resistencia inicial en el seno de un grupo de Madres de Plaza de Mayo hacia los procesos de identificación de restos humanos contrastó inicialmente con la búsqueda de Abuelas de Plaza de Mayo y otros sectores de Madres que encontraron en las técnicas de ADN algunas respuestas a sus búsquedas. Sin embargo, la definición del área de incumbencia del BNDG fue escenario de múltiples disputas entre los organismos de derechos humanos enfrentados entre una concepción amplia en vistas a atender la universalidad del derecho a la identidad y una más acotada asociada a la particularidad de una demanda histórica de reparación de las violaciones de derechos humanos cometidas durante la dictadura. En estas tensiones se entreveraban las demandas de nuevas formas de activismo de las víctimas, como Madres del Dolor - entre otras-que encontraban en las técnicas de ADN una solución tanto para inculpar o exculpar imputados de delitos sexuales como para prevenir la reincidencia de esos delitos. De este modo, la "verdad biológica" facilitada por el ADN dejaba de tener un sentido fundamentalmente reparatorio de los crímenes pasados, que tenía sustento en los procesos de restitución de identidad, para adquirir visos morales que la asociaban a la vigilancia genética y al punitivismo, reclamado por algunos sectores de familiares de las víctimas de la violencia sexual, entre otros involucrados. Sin duda, este nuevo sentido emergente de la "verdad biológica" generaba tensiones y disensos entre los actores involucrados en la discusión de incumbencias y delimitación de funciones del BNDG. Como vimos, estas iniciativas eran incluso rechazadas por sectores identificados con la lucha de las mujeres, que veían en esta adopción de la "verdad biológica" como factor determinante para esclarecer delitos sexuales una forma más de desoír la voz de las mujeres víctimas de esas violencias. Al mismo tiempo, quienes se habían movilizado en su condición de familiares y amigos de víctimas de la violencia institucional, como la asociación Luciano Arruga, o quienes se identificaban con las causas de trata de personas, buscaban mantener el alcance amplio del trabajo de reparación y restitución de la identidad llevado adelante por el BNDG desde sus orígenes, con el objeto de que incluyera a los desaparecidos en democracia. La solución alcanzada, que llevó a la creación de dos biobancos, fue eficaz para delimitar y distinguir las tareas de reparación del Estado con respecto a los crímenes del pasado, de las tareas de investigación criminal del presente y dejar fuera de la órbita estatal las demandas de las víctimas -y sus familiares - de las violencias estatales cometidas en democracia.

Esta división del trabajo fue concomitante de un proceso de jerarquización estatal de concepciones biopolíticas para diferenciar los saberes expertos del campo de los derechos humanos, reservando a los biólogos un papel privilegiado, a tono con las exigencias crecientes de adecuación a estándares internacionales de tratamiento de muestras biológicas y administración de técnicas de ADN.

En este decurso, el Estado avanza sobre algunos derechos ciudadanos, en nombre de otros, en particular, del "derecho a la verdad de las víctimas", devenido en un mandato incuestionado para legitimar tanto la extracción compulsiva de ADN como el almacenamiento de muestras biológicas por cien años, más allá del ciclo vital de los cuerpos vitales de los ciudadanos compelidos. En ese marco, "el derecho a la verdad de las víctimas" configura un régimen de verdad construido sobre la "prueba genética", que se vuelve casi incuestionado entre legisladores, actores judiciales, familiares, entre otros, y sitúa a los biobancos, y a sus elencos, a la par de los actores judiciales a la hora de administrar la reparación y el castigo. 
* Genética, derechos humanos y política estatal en la Argentina: la creación del Banco Nacional de Datos Genéticos y del Registro Nacional de Datos Genéticos vinculados a delitos sexuales

\section{REFERENCIAS}

Anitua, G. I. (2011). La Corte Suprema de Justicia de la Nación y la extracción de sangre a víctimas de delitos sin su consentimiento. Recuperado de http://www.pensamientopenal.com.ar/system/files/2011/06/doctrina29457.pdf\# view er.action $=$ download

Anred, (2014, 21 de junio) Mirta Baravalle: El Banco de Datos Genéticos del Hospital Durand es irremplazable. Recuperado el 21 de marzo de 2021 de https://www.anred.org/2014/06/21/ mirta-baravalle-el-banco-de-datos-geneticos-del-hospital-durand-es-irremplazable/

Barrera, L. (2012). Derecho y ciencia: ADN, conocimiento científico y práctica judicial. Papeles del Centro de Investigaciones, 2(5), 7-28.

Bergel, S. (2002). Los derechos humanos entre la genética y la bioética. Acta Bioethica, 8(2), 315-331.

Bernardi, P. y Fondebrider, L. (2007). Forensic archaeology and the scientific documentation of human rights violations: an Argentinean example from the early 1980s. En R. Ferllini. Forensic archaeology and human rights violations (pp. 205-232). Springfield: Charles C. Thomas.

Bernath, V. (2007). La identidad, historias reales del ADN. Buenos Aires: Planeta.

Cesaroni, C., Feldman, D. e Irrazábal, G. (2014). Reflexiones en torno a los 10 años de las leyes Blumberg'. Temperley, Buenos Aires: Tren en Movimiento Ediciones.

Carracedo, A., Salas, A. y Lareau, M. (2010). Problemas y retos de futuro de la genética forense en el siglo XXI. Cuadernos de Medicina Forense, 16(1-2), 31-35.

Caruso Fontán, V. (2012). Bases de datos oficiales sobre identificadores obtenidos a partir de ADN y derecho a la intimidad genética. Foro Nueva época, 15(1), 135-167.
Casado, M. y López Ortega, J.J. (coords.) (2015). Desapariciones forzadas de niños en Europa y Latinoamérica. Del convenio de la ONU a las búsquedas a través del ADN. Barcelona: Universidad de Barcelona.

Catoggio, M. S. (2019a). Futuros a prueba: derechos humanos, genética y creencias sociales. En A. Kozel, M. Bergel y V. Llobet (Eds.) El futuro: Miradas desde las humanidades. (pp. 225-245). Buenos Aires: UNSAM Edita. Recuperado de https://www.funintec.org. ar/contenidos/el-futuro-miradas-desde-lashumanidades/

Catoggio, M. S. (2019b). La construcción de la evidencia en la búsqueda de los desaparecidos: creencias, testimonios y saberes. Papeles del CEIC. International Journal on Collective Identity Research, 2, 216-233. Recuperado de https://www.ehu.eus/ojs/index.php/papelesCEIC/article/view/19461

Cohen Salama, M. (1992). Tumbas anónimas. Informe sobre la identificación de restos de víctimas de la represión ilegal. Buenos Aires: Catálogos.

Corach D., Penacino G. y Sotelo A. (1994). Dealing with human remains sampled in disaster areas the case of the Israelian Embassy explosion ocurred in Buenos Aires. En W. Bär, A. Fiori y U. Rossi (Eds.) Advances in forensic haemogenetics (pp. 5 y ss.). Berlín: SpringerVerlag. https://doi.org/10.1007/978-3-64278782-9_65

Corach, D., Sala, A., Penacino, G. y Sotelo, A. (1995). Mass disasters: rapid molecular screening of human remains by means of short tandem repeats typing. Electrophoresis, 16, 1617-1623. https://doi.org/10.1002/elps.11501601267

Di Lonardo, A. M., Orrego, C., Darlu, P., King, M. C. y Baur, M. (1984). Human genetics and human rights. Identifying the families of kidnapped children. The American Journal of Forensic Science and Pathology, 5(4), 339-347. 
Gatti, G. y Martínez, M. (2017). El ciudadanovíctima. Notas para iniciar un debate. Revista Estudios Sociales, 59, 8-13.

Gibbons, S. y Novas, C. (2007). Biosocialities, Genetics and the Social Sciences. Making Biologies and Identities. Londres: Routledge

Gesteira, S. (2014). Más allá de la apropiación criminal de niños: el surgimiento de organizaciones de personas 'adoptadas' que buscan su identidad biológica en la Argentina, Runa, 35(1), 61-76.

Gómez Ojero y Martínez, L. (2016). Genética y derechos humanos (Tesis doctoral no publicada). Universidad de Salamanca, Salamanca.

Goodwin, W. H. (2017). The use of forensic DNA analysis in humanitarian forensic action: the development of a set of international standards. Forensic Science International, 278, 221-227. https://doi.org/10.1016/j. forsciint.2017.07.002

Guerrero Moreno, A. (2011). La regulación de los datos genéticos y las bases de datos de ADN. Criterio Jurídico, 8(2), 1-22. Recuperado de https://revistas.javerianacali.edu.co/index. php/criteriojuridico/article/view/313

Hernández, M. A. (1996) La selección documental. Revista General de Información y Documentación, 6(3), 143-160.

Irrazábal, G., Dallorso, N., Cesaroni, C y Costa, N. (2018). Gestión de la inseguridad, violencias y sistema penal. Temperley, Buenos Aires: Tren en Movimiento.

Joyce, C. y Stover, E. (1991). Witnesses from the grave: the stories bones tell. Boston: Little Brown.

Kessler, G. y S. Gayol (2018) Muertes que importan. Una mirada sociohistórica sobre los casos que marcaron la Argentina reciente. Buenos Aires: Siglo XXI.

King, M. C. (1992). My mother will never forgive them. Grand Street, 41, 34-53. https://doi. org/10.2307/25007525

Kwong, K. (2017). The algorithm says you did it: the use of black box algorithms to analyze complex DNA evidence. Harvard Journal of Law \& Technology, 31(1), 276-301.

La Nación (2006, 17 de enero) . Para identificar a violadores. Genetistas instan a crear un banco de ADN de criminales. Recuperado el 17 de marzo de 2021 de lanacion.com.ar/sociedad/ genetistas-instan-a-crear-un-banco-de-adnde-criminales-nid772986/

López Beltrán, C., Wade, P., Restrepo, E. y Ventura Santos, R. (2017) Genómica mestiza. Raza, nación y ciencia en Latinoamérica. México, D. F.: Fondo de Cultura Económica.

Lorenc Valcarse, F. (2003). L'insécurité au pluriel. La construction politique- journalistique du problem de l'insécurité en Argentine (Memoria de Diploma de Estudios Avanzados sin publicar). Universidad de París I, París.

Machado H. y Granja, R. (2020) DNA databases and big data. En Forensic genetics in the governance of crime. Singapur: Palgrave Pivot. https:// doi.org/10.1007/978-981-15-2429-5_5

Maguire, C. N., McCallum, L. A., Storey, C. y Whitaker, J. P. (2014). Familial searching: a specialist forensic DNA profiling service utilizing the National DNA Database ${ }^{\circledR}$ to identify unknown offenders via their relatives: the UK experience. Forensic Science International: Genetics, 8(1), 1-9. https://doi.org/10.1016/j. fsigen.2013.07.004

McCartney, C., Wilson, T. y Williams, R. (2011). Transnational exchange of forensic DNA: viability, legitimacy and acceptability. European Journal on Criminal Policy and Research, 17(4), 305-322. https://doi.org/10.1007/s10610011- 9154-y

Osborn-Gustavson, A. E., McMahon, T., Josserand, M. y Spamer, B. J. (2018). The utilization of databases for the identification of human remains. En K. E. Latham, E. J. Bartelink y M. Finnegan (Eds.). New perspectives in forensic human skeletal identification (pp. 129-139). https://doi.org/10.1016/B978-0-12-8054291.00012-0 
* Genética, derechos humanos y política estatal en la Argentina: la creación del Banco Nacional de Datos Genéticos y del Registro Nacional de Datos Genéticos vinculados a delitos sexuales

Página 12 (2006, 15 de diciembre). El banco de datos genéticos ahora se quedó sin quórum. Recuperado el 21 de marzo de 2021 de https://www.pagina12.com.ar/diario/elpais/1-77758-2006-12-15.html

Parra, R., Zapico, S. y Ubelaker, D. (2020). Forensic Science and humanitarian action, interacting with the dead and the living (2 vols.). Nueva Jersey: Wiley.

Paz Karaman, P. (2015). Biobancos: casos de estudios y lecciones para Colombia. Direito Sanitário, 16(3), 102-121.

Penacino, G. A. (2008). The new genetic database of Argentina. Forensic Science International: Genetics Supplement Series, 1(1), 658-659. https://doi.org/10.1016/j.fsigss.2007.10.017

Penchaszadeh, V. (2012). Reflexiones sobre genética y derechos humanos. Encuentros y desencuentros. Buenos Aires: Paidós.

Pérez Hernández, C. (2002). Explotación de los córpora textuales informatizados para la creación de bases de datos terminológicas basadas en el conocimiento. Iris, 18 [en línea]. Recuperado de http://elies.rediris.es/ elies18/index.html

Pestoni, M.C. y Carracedo Álvarez, A. (1998). Aspectos éticos del uso de la prueba de ADN con usos forenses. En A. Cambrón Infante (Ed.). Entre nacer y morir (pp. 153-164). Granada: Comares.

Pitch, T. (2003). ¿Mejor los jinetes que los caballos? El uso del potencial simbólico de la justicia penal por parte de los actores en conflicto. En Responsabilidades limitadas, actores, conflictos y justicia penal (pp. 125-159). Buenos Aires: Ad-Hoc.

Roberts, D. (2011). Collateral consequences, genetic surveillance, and the new biopolitics of race. Howard Law Journal, 54(3), 567-585.

Rose, N. ([2007]2012). Políticas de la vida. Biomedicina, poder y subjetividad en el siglo XXI. Buenos Aires: Unipe.
Sánchez, D., Carracedo, M. y Abraham, D. (2017). Consentimiento informado en biobancos y bases de datos. Anales de la Facultad de Medicina, 4, 31-36. Recuperado de http://anfamed.edu.uy/index.php/rev/article/view/312

Santaló, J. y Casado, M. (Coords.) (2016). Documento sobre bioética y edición genómica en humanos. Depósito Digital de la Universidad de Barcelona. Recuperado de http://diposit. ub.edu/dspace/handle/2445/105022

Smith, L. (2017). The missing, the martyred and the disappeared: Global networks, technical intensification and the end of human rights genetics. Social Studies of Science, 47(3), 398-416.

Sodini, D. y Garbi, S. (Coords.) (2014). Seguridad pública, violencias y sistema penal. Temperley, Buenos Aires: Tren en Movimiento.

Suter, S. (2010). All in the family: privacy and DNA familial searching. Harvard Journal of Law \& Technology, 23(2), 310-399.

Valles, M. (1997). Técnicas cualitativas de investigación social. Reflexión metodológica y práctica profesional. Madrid: Síntesis.

Vargas Ávila, R. (2010). La valoración de la prueba científica de ADN en el proceso penal Prolegómenos. Derechos y Valores, 13(25), 127-146.

Wagner, S. (2008). To know where he lies: DNA technology and the search for Senebrica's missing. Berkeley, California: University of California Press.

Zaffaroni, E. R. (2009). Estructura básica del derecho penal. Buenos Aires: Ediar.

\section{Fuentes legislativas y jurídicas citadas}

Banco Nacional de Datos Genéticos (19807). Ley 23511. Su Creación. Boletín Oficial 14, 26676: 2-3 (10 de julio de 1987). Buenos Aires: HSDN.

Comisión de Justicia y Asuntos Penales del Senado de la Nación. (2004). Debate en comisión. 
Recuperado de http://www.pensamientopenal.com.ar/system/files/2014/12/legislacion30082.pdf

Honorable Cámara de Diputados de la Nación (2006) Período 124 reunión 52 Instituto Nacional de Datos Genéticos para el Esclarecimiento de de Delitos de Lesa Humanidad. 13/12/2006. Recuperado de: https://www. hcdn.gob.ar/diputados/aabraham/discursos/ debate.jsp?p=124,52,21

Honorable Cámara de Diputados de la Nación (2009, 11 de septiembre). Recuperado de https://www4.hcdn.gob.ar/dependencias/dsecretaria/Periodo2009/PDF2009/ TP2009/0023-PE-09.pdf

Honorable Cámara de Diputados de la Nación (2009, 4 de noviembre) 15ạ Reunión, 9a Sesión ordinaria. Periodo 127.

Honorable Cámara de Diputados de la Nación, (2013, 3 de julio). $8^{\circ}$ reunión, $6^{\circ}$ sesión, periodo 131.

Honorable Cámara de Senadores de la Nación (1986, 31 de octubre). 32 o reunión, 23ํㅗㅇ sesión extraordinaria. Buenos Aires: HSDN.

Honorable Cámara de Senadores de la Nación (2011, 31 de agosto). 10ª reunión, 8a sesión ordinaria.

Honorable Cámara de Senadores de la Nación, (2009, 18 de Noviembre). 17ํㅡ reunión, 13으 sesión ordinaria.

Honorable Cámara de Senadores de la Nación. (2010). Expte. 3370/10. Texto definitivo (sancionado) completo CD-232/11. Registro Nacional de Datos Genéticos Vinculados a Delitos contra la Integridad Sexual. Creación. Buenos Aires: HCSN.

Instituto Nacional de Datos Genéticos para el Esclarecimiento de Delitos de Lesa Humanidad.
(2006, 5 de octubre) Expediente 5899-D2006. Creación en el ámbito del Ministerio de Justicia y Derechos Humanos. Buenos Aires: HCDN. Recuperado de https:// www.diputados.gob.ar/comisiones/permanentes/cpyhacienda/proyectos/proy ecto. jsp?exp=5899-D-2006

Ley 25.087. (1999, 7 de mayo). Delitos contra la integridad sexual. Modificación 7 de mayo de 1999. Recuperado de http://servicios. infoleg.gob.ar/infoleglnternet/anexos/5500059999/57556/norma.htm

Ley 26.738. (2012). Delitos contra la Integridad Sexual. Modificación. 4 de abril de 2012. Recuperado de http://servicios.infoleg.gob.ar/infoleglnternet/anexos/195000- 199999/195896/ norma.htm

Ley 26548. Banco Nacional de Datos Genéticos. Ámbito Funcional. Objeto. Funciones. Boletín Oficial 31790: 1 (27 de noviembre de 2009).

Mestre, R. (2010). Expte. 3370/10. Modificación Ley 22.117. Registro Especial de Delitos contra la Integridad Sexual. Creación. Buenos Aires: HCSN.

Ministerio de Justicia de la Nación. (2004). Resolución 415/2004. Registro de huellas digitales genéticas. Recuperado de http://servicios. infoleg.gob.ar/infolegInternet/anexos/9500099999/95342/norma.htm

Poder Ejecutivo Nacional - PEN (2017). Decreto 522/17. Delitos contra la Integridad Sexual. Recuperado de http://servicios.infoleg.gob. ar/infolegInternet/verNorma.do?id=276961

Registro Nacional de Datos Genéticos (2013, 24 de julio). Ley 26879. Delitos contra la integridad sexual. Creación. Boletín Oficial 31686. 